\title{
LEADER ENDORSEMENT: THE ROLE OF LEADER PROTOTYPICALITY, LEADER EFFECTIVENESS AND EMPLOYEE'S ORGANIZATIONAL IDENTIFICATION
}

\author{
Taufik Nur Rochman ${ }^{1}$, Samian Samian ${ }^{2}$, Corina D. Riantoputra ${ }^{1}$ \\ ${ }^{1}$ Faculty of Psychology, Universitas Indonesia \\ ${ }^{2}$ Faculty of Psychology, Universitas Airlangga \\ corina.r@ui.ac.id
}

\begin{abstract}
Leadership occurs when the individuals claimed capable of leading, received endorsements from their subordinates. Without endorsements (i.e., subordinates' willingness to support and be directed by the leader), no leader will be able to direct and influence their subordinates. Using the Social Identity Theory of leadership, this research aimed to investigate the factors influencing leader endorsement. Through an online survey with good internal consistency (i.e., coefficient reliability ranging from .7 to .9), this study was able to collect data from 186 private employees across Indonesia. The moderated multiple regression analysis showed 1) subordinates tend to endorse prototypical leaders; 2) organizational identification is positively related to leader endorsement; and 3) leader effectiveness weakens the positive relationship between leader prototypicality and leader endorsement. This study contributes to the social identity theory of leadership by demonstrating that low prototypical leaders may still get endorsed, as long as they are showing effective behavior. This new finding sheds light on what kind of leadership behaviors may win the endorsement from their subordinates.
\end{abstract}

Keywords: leader endorsement; social identity theory; leader effectiveness; leader prototypicality; Indonesia.

\begin{abstract}
Abstrak
Kepemimpinan dalam hubungan relasional akan terbentuk jika terdapat klaim dari seorang individu bahwa dirinya sanggup memimpin dan klaim tersebut diterima serta diberikan dukungan (endorsement) oleh individu di sekitarnya. Menggunakan social identity of leadership theory, penelitian ini bertujuan menguji faktor-faktor yang memengaruhi pemberian endorsement kepada pemimpin. Data dikumpulkan melalui survei daring dengan reliabilitas alat ukur berkisar antara 0,7 - 0,9. Teknik pengambilan sampel menggunakan convenience sampling. Sampel dalam penelitian ini sebanyak 186 pekerja swasta di Indonesia. Berdasarkan hasil analisis moderated multiple regression menunjukkan bahwa: (1) bawahan memberikan endorsement kepada pemimpin yang prototipikal, (2) bawahan yang memiliki organizational identification akan memberikan endorsement kepada pemimpin, (3) efektivitas pemimpin cenderung memperlemah hubungan positif antara leader prototypicality dengan leader endorsement. Penelitian ini berkontribusi untuk menjelaskan bagaimana persepsi atas seberapa jauh pemimpin dianggap merepresentasikan karakteristik organisasinya dan mengidentifikasi bawahan terhadap organisasinya dapat memengaruhi pembentukan leader endorsement. Selain itu penelitian ini juga berkontribusi menjelaskan bagi para pemimpin di organisasi tentang perilaku seperti apa yang sebaiknya ditampilkan untuk mendapat dukungan dari bawahan.
\end{abstract}

Kata kunci: leader endorsement; leadership identity; leader effectiveness; leader prototypicality

\section{INTRODUCTION}

The classic leadership study explains that the leadership process takes place in a leadercentric manner known as the great men theory (Haslam, Reicher, \& Platow, 2011). According to this classic approach, leadership occurs because of the presence of great individuals with natural talents who can carry out leadership (Haslam et al., 2011). However, since mid-1970, the direction of leadership studies began to shift to the relational process between individuals where subordinates play a central role in the leadership process (Uhl-Bien, Riggio, Lowe, \& Carsten, 2014). Recently, leadership 
studies describe leadership as a relational process that involves two parties with the intention of one cannot be a leader if he does not have subordinates to lead (Marchiondo, Myers, \& Kopelman, 2015). Similarly, Dutton, Roberts, and Bednar (2010) also describe leadership as a progression that arises not only from within the leader (the individual believes that he can lead) nevertheless also involves the perception of others as subordinates in relational relationships. Otherwise, a person cannot be a leader without the subordinates' agreement and willingness to be subordinate.

Since this research views leadership as a relational process involving individuals in organizations, the precise theory to explain this process is the social identity theory of leadership. The rudimentary principle of this theory is that relational relationships have a significant role, especially in the process of social identification between individuals involved in the same organization (Hogg, Rast, \& van Knippenberg, 2012). This philosophy sees leadership as a relational relationship between leaders and subordinates that becomes interdependent because it is binding by group membership (Hogg et al., 2012). Further, it explains that in organizational life, individuals will get an understanding related to self-concepts that are influenced by their social groups where they belong or referred to as collective self (UhlBien et al., 2014). In the process of forming the self-concept, the social identity confined in the organization will influence and shape the individual's perception related to themselves such as values, orientation, norms, and goals (Haslam, 2014). It also determines individual's perception in relation to what they should think about, what they should do, and what they should achieve to enrich the organization (Haslam, 2014), which then will influence interactions in organizations.

Based on the social identity theory of leadership, Derue and Ashford (2010) explained that the leadership process will always be formed through a claiming- granting mechanism. This mechanism explains why individuals become leaders and other individuals become subordinates. Rendering to this mechanism, leadership will emerge in the relational process when an individual claims that he is a leader, and the individual around him approves the claim and then gives a grant (in the form of endorsement) to the entitlement. When this process occurs, a reciprocal relationship or positive spiral will be created (DeRue \& Ashford, 2010). Nonetheless, if someone claims to be a leader while their subordinates are unwilling to endorse or support them, then, the claiming-granting mechanism will be unsuccessful or DeRue and Ashford (2010) called this condition as negative spiral. Hence, granting in the form of endorsement is a vital factor to guarantee the successively of the leadership process.

Leader endorsement is a crucial part of the leadership process. Several previous studies have tried to define a leader endorsement. It is the process when subordinates obtain and deliver support for individual claims to be leaders (Riyadi, Asakurnia, Wijaya \& Riantoputra, 2019). Leader endorsement can also be interpreted as receiving claims and sustenance given to a consider appropriate organization leader or organization (Graf, Schuh, van Dick, \& van Quaquebeke, 2012). Meanwhile, Gleibs and Haslam (2016) define leader endorsement as the process of receiving claims and providing provision to leaders to preserve and enhance group performance.

Previous research explains that the formation of leader endorsement can be influenced by various factors, both internal (from the individual side, i.e., subordinates and superiors) or external. Leader endorsement can be influenced by factors on the individual side such as follower's self-uncertainty regarding their identity (Rast, Gaffney, Hogg, \& Crisp, 2012), follower cognitive needs (Rast, Hogg, \& Tomory, 2015), and how far follower identify leader (Rast, Hackett, Alabastro, \& Hogg, 2015) and group 
orientation from the leader (Graf et al., 2012). Leader endorsement can also be influenced by external factors, for example in terms of organization, the formation of leader endorsement can be influenced by relationships between groups within the organization (Gleibs \& Haslam, 2016), as well as objectives to be achieved (Spisak, Grabo, Arvey, \& van Vugt, 2014).

In leadership studies, leader endorsement has several important roles. Peters and Haslam's (2018) states that although an individual displayed leader-like behavior, without subordinates' endorsements they will not be viewed positively as leaders. This is because subordinates will give supports and approvals only when the leader characteristics represent the organization's values (Peters \& Haslam, 2018). Endorsement given to a leader will also form a positive leader identity (Derue \& Ashford, 2010) so that leaders could assert their influence. De Cremer, van Dijke, and Mayer (2010) found the impact of a leader who is given an endorsement will be considered more representative of the values and norms of the organization to produce a positive relationship and be considered more able to be fair. However, another study also demonstrated that leaders' endorsement has an indirect negative impact that could lead to abusive behavior, when paired with weak collective identities of their subordinates (Johnson, Venus, Lanaj, Mao, \& Chang,2012)

To elucidate the leader endorsement process, the social identity theory of leadership explains that information related to values and characteristics of the organization will convince individuals in an organization about the concept of "who we are" (Hogg et al., 2012). According to the social identity theory of leadership individuals in the organization will always attempt to define "who are we? What steps should be taken to define us?" According to this theory, this process of selfdefinition, can only be triggered by leaders who are considered to have similar values and characteristics with the organization and its members (Hogg et al., 2012). According to this theory, leaders with similarity characteristics, values, and vision with their organizations are called prototypical leaders (Barreto \& Hogg, 2017). This study will see whether the prototypical leader influences the formation of leader endorsement.

Previous studies have found that prototypical leaders reap many positive results that lead to the emergence of support for the prototypical leader (Barreto \& Hogg, 2017). Generally, prototypical leaders will be evaluated more positively by subordinates than nonprototypical ones (Barreto \& Hogg, 2017). In their meta-analysis study, Bareto and Hogg (2017) shows that thirty-five studies about leader prototypicality found that prototypicality was positively related to trust, support, and positive evaluation towards leaders. Rast et al. (2015) stated the prototypical leader would stand his leading failure and still be viewed positively. Prototypical leaders are also more supported and trusted when making innovations in organizations (Goldman \& Hogg, 2016). Leader prototypicality can also be a factor used by subordinates to "separate" individuals who are considered to be leaders and those who are not (Braun, Peus, \& Frey, 2018). The reason is subordinates see a good leader as a leader who has similar characteristics, values, and vision with the organization (Braun, Peus, \& Frey, 2018).

The prototypical leader will also be a role model and chosen to promote group dynamics (Grille, Schulte, \& Kauffeld, 2015). In their study, Seppälä, Lipponen, Bardi, and PirttiläBackman (2012) stated that a prototypical leader would be more trusted even though they do not flaunt fairness behavior compared to non-prototypical leaders. In the leadership process, the prototypical leader will also be used as a role model in the process of social relationship construction (Lau, Bligh, \& Kohles, 2019). On grounds in a process that involves a relational relationship, the prototypical leader will become a trusted source of information including when subordinates experience uncertainty 
regarding "who we are?" (Rast et al., 2012; Uhl-Bien et al., 2014). Distinct research also shows the prototypical leader will be stronger in the high-identifier follower because this type of subordinate will only be fixated on the leader with the ability to govern and given the solution (Uhl-Bien et al., 2014). For this reason, based on the literature review that has been done, leaders who have prototypicality have many features in the leadership process because they are considered as trusted figures who provide influence and information in organizations. Hence, the first hypothesis formulated in this study is

H1: Leader prototypicality will be positively correlated to leader endorsement.

By using the social identity theory of leadership, the process of providing an endorsement to a leader occurs in the relational process between leaders and subordinates (DeRue \& Ashford, 2010). It means that subordinates also have a role by actively identifying themselves with elements of organizations which this process called as organizational identification (OI) (Lee, Park, \& Koo, 2015). OI is a process where an individual in an organization formed his selfconcept which was derived from identification on organization various elements which will ultimately influence the formation of behavior (Karanika-Murray, Duncan, Pontes, \& Griffiths, 2015). Brown (2017) explicates that OI is an aligning process between one's view and the collective view of the organization which results in the emergence of a sense of unity between oneself and the organization. Social identity theory states that $\mathrm{OI}$ is formed from an individual's knowledge of his organization where this knowledge is formed seeing as the individual feels as member or part of the organization (Brown, 2017; He \& Brown, 2013).

Brown (2017) stated that the impact of the emergence of OI on employees is the process of aligning and accepting various elements in the organization ranging from goals, beliefs, behavior, and stereotypic traits. Based on social identity theory, acceptance of various elements in organizations also includes accepting the relational relationship between employees and their leaders in the organization (He \& Brown, 2013). Because an employee who has high identification with his/her organization has a sense of being united with the organization, the employee has let go his personal view of "how is it right?" or "what behavior should be displayed?" (Meleady \& Crisp, 2017). This process will make the employee becomes more supportive with every policies of the organization, including when the organization appoints leader (Meleady \& Crisp, 2017). This is understandable considering that subordinates with high identification to the organization have views that prioritize the interests of the organization rather than their self-interests (Lee et al., 2015).

Based on the explanation on OI above, it can be seen that employees acceptance of all organizational policies, including leaders, so that it will be seen whether employees who have identification of the organization will receive and provide support (endorsement) to the leader in the organization. This is due to one of the principles of $\mathrm{OI}$ is that employees will form a self-concept following the collective view of the organization, one of which is influenced by the values and information conveyed by the leaders (Meleady \& Crisp, 2017). It means that in the process of identification between individuals and organizations, leaders can be considered as providers of information that contribute to the formation of collective behavior and views between employees and their organization (Meleady \& Crisp, 2017). Further, it expresses the second hypothesis, explicitly:

H2: Subordinate organizational identification will be positively correlated to leader endorsement. 
According to the social identity theory of leadership, relational leadership will provide various benefits to leaders who have similar characteristics (prototypical leaders). However, some previous research findings suggest that the relationship between leader prototypicality and leader endorsement can be strengthened or weakened, for example by employees Need for Cognition (NC) (Rast et al., 2015) or uncertainty experienced by subordinates (Rast et al., 2012). A study in Indonesia found that prototypicality was not a significance predictor of leader endorsement (Nugraha, Samian, \& Riantoputra, in press). Social identity theory of leadership explains that the perception of whether or not a leader is prototypical may be beneficial, but it is not a mandatory requirement for leaders to get an endorsement (Steffens, Haslam, \& Reicher, 2014). Consistent with Reicher, Haslam, and Platow (2018) the similarity of the characteristics and support of leaders is not something that already exists that is only obtained from the perception of subordinates but can be influenced by actions and positive behaviors' that are carried out by these leaders. This positive behavior is then called leader effectiveness.

There are several behaviors that leaders can perform to be accepted and get positive support and evaluation (Meleady \& Crisp, 2017). One of the behaviors that can be pursued by the leader is by behaving effectively, specifically communicating ideas and values to other individuals in the organization and realizing those ideas and values in the form of positive behavior that helps realize the goals of the organization (Hogg et al., 2012 ). Based on the perspective of the social identity theory of leadership, effective leaders can mobilize and motivate subordinates to achieve collective objectives such as goals, vision, and mission of the organization (van Knippenberg, 2011). Positive subordinate views on effective leaders are also formed because effective leaders will focus more on the needs of the organization and not always focus on themselves (Martin, Cote, \& Woodruff,
2016). Ewen et al. (2013) stated leader effectiveness occurs not only when the leader displays positive behavior to achieve organizational goals, but also when subordinates are satisfied with the steps taken by the leader. Therefore, it can be concluded that the effective behavior displayed by the leader will bring up a positive evaluation given to the leader by subordinates.

As maintained by Hannah, Sumanth, Lester, and Cavarretta (2014), the effectiveness of leaders not only comes from leaders' decisions to do constructive things but also influences how subordinates assess and perceive the behavior of their leaders. As demonstrated by Duarsa and Riantoputra (2017) in their research of Indonesia leaders, that employees tend to perceive their leaders as effective when they have good relationships with their leaders. This is because, in the mechanism of claiminggranting, the ability or competence of leaders in displaying positive behavior and helping organizations achieve goals can also affect the granting of subordinates (Marchiondo et al., 2015). Based on the explanation above, it can be assumed that prototypical leaders who also display effective behavior will increasingly get the endorsement from subordinates. Leaders who have comparable characteristics with their organizations will be increasingly supported when presenting concrete actions in the form of leader effectiveness. It showed that the leader deserves endorsement from subordinates. For this reason, this research formulates a third hypothesis, namely:

H3: Leader effectiveness will strengthen the positive relationship between leader prototypicality and leader endorsement.

\section{METHOD}

This study uses a quantitative approach with a non-experimental design to see what factors can influence the formation of leader endorsement. The population of the study participants was all private employees in Indonesia. The sampling technique used is 
convenience sampling in terms of participants' accessibility. Participants were employees in private companies with at least one year of work experience. The private companies came from Greater Jakarta, Central Java, West Java, West Sumatra, South Sumatra, and South Sulawesi. The consideration for choosing a private company is because a government office (for example, a ministry, military, or police) has a hierarchical structure whose leaders are directly appointed by superiors. This type of organization makes anyone who is appointed will immediately get the authority and legitimacy and automatically given endorsement from subordinates (Derue \& Ashford, 2010). Thus, we decided that private companies can better describe the process of forming a leader endorsement.

A total 186 employees were participated (56,5 $\%$ men and the rest were women, $\mathrm{M}_{\text {age }}=26,18$ years, $S D=3,60 ; M_{\text {tenure }}=3,35$ years, $S D=$ 3,$82 ; \mathrm{M}_{\text {tenure on current division }}=2,74$ years, $S D=$ 3,$43 ; \mathrm{M}_{\text {tenure on current leader }}=2,56$ years, $S D=$ 3,28). Data were collected within 7 days by self-report using an online questionnaire with a 6-point Likert type scale $(1=$ strongly inappropriate until $6=$ strongly appropriate). The research questionnaire includes an introduction, study description, informed consent, and procedures. The instruments were leader prototypicality, leader effectiveness, organizational identification and leader endorsement. Besides, the participants were completing organizations and leaders' demographic data such as work years' experience, division, the leader educational background. In the last part of the questionnaire, they given the opportunity to receive the reward. Participants were also given information that the data taken was guaranteed confidentiality and only used for research purposes.

The instruments were adapted from previous studies. The original English scale is translated into Bahasa Indonesia with expert approval. After that, a readability test was taken in the pilot study. Leader prototypicality was assessed with five items derived from Platow and van Knippenberg (2001). On this scale, employees assess how prototypical their leader is. Examples of statements are "This team leader is a good example of the kind of people that are a member of my team "and "This team leader represents what is characteristic about the team" (scale reliability coefficient .86). Leadership effectiveness was assessed with 14 items derived from DeGroot et al. (2012). On this scale, employees assess how effective their superior leadership is. Examples of statements are "The leader gives ideas to solve team's problems "and "The leader helps to identify teams' goals" (scale reliability coefficient .94). Leader endorsement was measured with 6 items which adapted from the Michener and Lawler (1975). On this scale, employees assess how far they support their direct leader. Examples of statements are "I am willing to work with my direct leader" and "I am satisfied with the performance of my direct leader in directing the team" (scale reliability coefficient .93). Whereas Organizational Identification (OI) was measured using 6 items adapted from the Mael and Ashforth (1992). On this scale, employees rate how highly they feel united with the organization. Examples of statements are "The firm's successes are my successes" and "when someone praises this company, I feel it as personal praise" (scale reliability coefficient .72).

Further, the relational demography between employees and leaders were controlled. Relational demography defined as similarity and dissimilarity between demographic factors between leaders and employees (such as differences in sex, age, educational background, and ethnicity) (Chattopadhyay, George, \& $\mathrm{Ng}$, 2016). Further, relational demography affected the relational relationship and individuals' group identification, also influences individuals' organization attitude and behavior (Chattopadhyay, George, \& Ng, 2011). The 
literature expressions that to measure relational demography, the method used is by coding and does not necessitate a specific measurement scale. For instance, in measuring sex dissimilarity, Luksyte and Avery (2015) give code 0 if subordinates and leaders have the same sex, conversely 1 if subordinates and leaders have different sexes. This study will control the demographic differences between subordinates and leaders in terms of age, sex, education, and religion.

Data analysis was performed using moderated multiple regression analysis with SPSS v.25. Cohen (2003) required to do mean-centered for moderated multiple regression analysis so that the centering process has been carried out for moderator and predictor variables.

\section{RESULTS AND DISCUSSION}

The first step is to look at the correlation between variables in the correlational analysis. The results in table 1 show that the differences in education levels between subordinates and superiors were negatively significantly correlated with leader endorsement ( $r=-.20 ; \mathrm{p}<.01)$. Furthermore, this variable will be controlled in a regression analysis to test the research hypothesis.

Table 1.

Correlation Between Variables

\begin{tabular}{|c|c|c|c|c|c|c|c|c|c|c|c|c|c|c|}
\hline & $\mathrm{M}$ & SD & 1 & 2 & 3 & 4 & 5 & 6 & 7 & 8 & 9 & 10 & 11 & 12 \\
\hline 1.Gender & - & - & 1 & & & & & & & & & & & \\
\hline $\begin{array}{l}\text { 2. Age Deviation } \\
\text { (Follower-Leader) }\end{array}$ & 14,20 & 8,37 & -.07 & 1 & & & & & & & & & & \\
\hline $\begin{array}{l}\text { 3. Age Difference } \\
\text { (Follower-Leader) }\end{array}$ & - & - & -.04 & $-.45^{* *}$ & 1 & & & & & & & & & \\
\hline $\begin{array}{l}\text { 4.Educational } \\
\text { background } \\
\text { differences } \\
\text { (Follower-Leader) }\end{array}$ & - & - & -.12 & $-.19^{* * *}$ & $.21^{* *}$ & 1 & & & & & & & & \\
\hline $\begin{array}{l}\text { 5.Religion } \\
\text { differences } \\
\text { (Follower-Leader) }\end{array}$ & - & - & $.26^{* *}$ & -.14 & .05 & $-.18^{*}$ & 1 & & & & & & & \\
\hline $\begin{array}{l}\text { 6.Number of } \\
\text { employees }\end{array}$ & - & - & $.17^{*}$ & -.11 & -.06 & $-.24^{* *}$ & .11 & 1 & & & & & & \\
\hline $\begin{array}{l}\text { 7. Work years in } \\
\text { company }\end{array}$ & 3,35 & 3,82 & -.03 & $-.23^{* *}$ & $.44^{* *}$ & .03 & .04 & -.12 & 1 & & & & & \\
\hline $\begin{array}{l}\text { 8. Work years in } \\
\text { Division }\end{array}$ & 2,74 & 3,43 & -.06 & $-.17^{*}$ & $.26^{* *}$ & .03 & .04 & -.10 & $.91^{* *}$ & 1 & & & & \\
\hline $\begin{array}{l}\text { 9. Work years under } \\
\text { the leader }\end{array}$ & 2,56 & 3,28 & -.02 & -.10 & .12 & -.00 & .08 & -.09 & $.85^{* *}$ & $.92^{* *}$ & 1 & & & \\
\hline $\begin{array}{l}\text { 10.Leader } \\
\text { Prototypicality }\end{array}$ & 4,23 & 0,91 & -.00 & $-.19^{* *}$ & $.15^{*}$ & -.12 & .02 & $.19^{* * *}$ & .10 & .02 & .01 & 1 & & \\
\hline $\begin{array}{l}\text { 11.Organizational } \\
\text { Identification }\end{array}$ & 4,61 & 0,72 & -.11 & -.09 & .03 & -.07 & -.05 & -.03 & .04 & .01 & .01 & $.39^{* * *}$ & 1 & \\
\hline $\begin{array}{l}\text { 12.Leader } \\
\text { Effectiveness }\end{array}$ & 4,37 & 0,91 & -.10 & -.06 & .11 & -.13 & .01 & -.03 & .13 & .09 & .09 & $.66^{* *}$ & $.29^{* *}$ & 1 \\
\hline $\begin{array}{l}\text { 13.Leader } \\
\text { Endorsement }\end{array}$ & 4,44 & 1,15 & .00 & -.07 & .09 & $-.20^{* * *}$ & .07 & .13 & .13 & .10 & .10 & $.69^{* *}$ & $.39^{* *}$ & $.74^{* *}$ \\
\hline
\end{tabular}

$* \mathrm{p}<.05 ; * * \mathrm{p}<.01$

As can be seen in Table 2, the regression model can explain $68 \%$ of the variance of the leader endorsement variable $(\mathrm{F}[6.78]=76.49$, $p=.00<.01)$. The results showed that leader prototypicality is positively correlated to leader endorsement $(\beta=.34, \mathrm{SE}=.07)$. Then, hypothesis 1 is accepted and supported by data. The more prototypical the leader is, the greater the endorsement that will be given to the leader. The analysis also showed that organizational identification is significantly 
correlated to leader endorsement $(\beta=.20, \mathrm{SE}$ $=.07$ ), then hypothesis 2 is supported by data. It found that the more subordinates identify themselves with organization, the higher the endorsement that will be given to the leader. Further, even though the relationship is not as hypothesized, it is shown that leader effectiveness significantly acts as a moderator in the relationship between leader prototypicality and leader endorsement $(\beta=$ $.18, \mathrm{SE}=.04)$. Hypothesis 3 is rejected. It is shown that leader effectiveness weakens the positive relationship between leader prototypicality and leader endorsement.

Table 2.

Moderated Multiple Regression Results Outcome Variable: Leader Endorsement

\begin{tabular}{lccc}
\hline \multicolumn{1}{c}{ Variable } & Step 1 & Step 2 & Step 3 \\
Differences of educational background (Follower- & $-.37 *$ & -.16 & -.08 \\
Leader) & - & $.39 * *$ & $.34 * *$ \\
Leader Prototypicality & - & $.19^{*}$ & $.20^{* *}$ \\
Organizational Identification & - & $.62 * *$ & $.54 * *$ \\
Leader Effectiveness & - & - & $-.18^{* *}$ \\
Prototypicality X Leader Effectiveness & .04 & .65 & .68 \\
R2 & .04 & .61 & .02 \\
$\Delta \mathrm{R}$ & 7.76 & 84.89 & 76.49 \\
F & 6.77 & 3.89 & 6.78 \\
df1,df2 & & & \\
\hline
\end{tabular}

Also, to see the interaction of leader effectiveness as a moderator, a simple slope analysis is performed. Figure 1 shows that the leader with the highest endorsement leader is the leader with high prototypicality and effectiveness. Further, Figure 1 demonstrates that leaders with low prototypicality but high effectiveness will be more supported than high prototypical leaders but low effectiveness. Furthermore, the leader who gets the lowest endorsement has shown both low prototypicality and effectiveness. The higher the leaders' effectiveness, the lower the role of the prototypical leader to the leader endorsement, which is indicated by the increased slope. In other words, there are opportunities for low prototypical leaders to continuingly strive to get the endorsement from employees through work effectiveness.

The present study aimed to portray how leader endorsements are formed in the leadership process. The factors analyzed to determine the formation of leader endorsement are leader prototypicality, organizational identification, and leader effectiveness. The results showed that leader prototypicality is positively related to leader endorsement, meaning that the more prototypical a leader is, the higher the endorsement that will be obtained. It is consistent with the previous study which showed that prototypical leaders would be given support (Barreto \& Hogg, 2017).

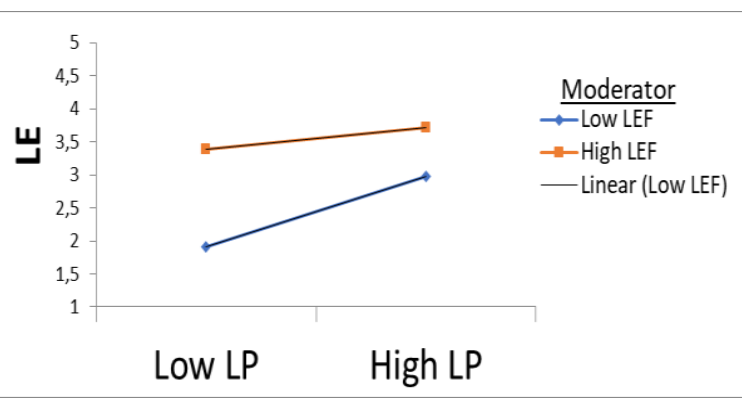

LE: Leader Endorsement; LP: Leader Prototypicality; LEF: Leader Effectiveness

Figure 1. Slope Analysis

Social identity theory articulates that individuals in organizations will continue to evaluate the relationship between themselves and the organization including their leaders (Karanika-Murray et al., 2015). The positive 
relations between leader prototypicality and leader endorsement occurs because prototypical leaders have desirable group characteristics (Epitropaki, Kark, Mainemelis, \& Lord, 2017). This mechanism takes place because of the triangular similarity in characteristics between leaders, organizations, and employees so that subordinates view leaders as an influential factor (Epitropaki et al., 2017)

The positive relationship between leader prototypicality and leader endorsement also occurs because subordinates interpret the prototypical leader as a trusted source of information and can provide clarity about the goals of their organization (Hogg, 2016). Because prototypical leader are seen as trusted source of information, prototypical leaders can reduce the uncertainty of subordinates regarding organizational identity so that subordinates are more confident to provide support (Hohman, Gaffney, \& Hogg, 2017). Besides, prototypical leaders are considered to represent the characteristics of the organization, so that support and morale from subordinates will also upsurge because they are led by people who have similarities with their organization (Gerpott, Van Quaquebeke, Schlamp, \& Voelpel, 2019).

Also, the results designate that organizational identification (OI) is positively related to leader endorsement. It shows that the more subordinates identify the organization, the greater their tendency to endorse their leaders. Several previous studies indicate that the higher the level of identification of subordinates in an organization, the more understanding, knowledge, and commitment are formed from the individuals to achieve organizational goals (Ng \& Feldman, 2010; Oktug, 2013). Commitment to achieving organizational goals is shown by providing support to leaders who display effective behavior. Subordinates will provide support to leaders who are considered capable of achieving organizational goals $(\mathrm{Ng} \&$
Feldman, 2010). Besides, other explanations of the findings of this study are found in Bal, de Cooman, and Mol's (2013) examination, which says that the higher the subordinates' organization identification, the more they are attached to various aspects of the organization including the leader. It makes subordinates become increasingly involved with their leaders which leads to the formation of endorsement of existing leaders (Lee et al., 2015).

The analysis shows that the effectiveness of the leader weakens the positive relationship between the prototypical leader and the endorsement leader. There are several explanations related to the results of this analysis. The weakening of the prototypical role of leaders when moderated by the effectiveness of leaders is explained by Haslam et al., (2011) and Steffens et al. (2014) which said in the development of leadership in relational relationships, to be a leader is not just about "one of us" but what must be considered is "embed a sense of us" which is manifested through the positive behavior of leaders. This means that the similarity of characteristics between leaders and organizations becomes less important when a leader manages to create a cohesive state with subordinates through effective behavior. It can also be explained by previous research which states that in the context of relational relationships, leaders can spread their influence and get provision by demonstrating behavior, values, and trust so that subordinates view effective behavior as an effort that benefits organizations to move forward (Reicher et al., 2018). Within the scope of the relational relationships between leaders and subordinates, it confirmed Hogg et al. (2012) in social identity theory that says leaders who are perceived as effective leaders will be accepted and supported because they are considered to be able to maintain the value of the organization and improve performance. In the rules of social identity theory, subordinates will always look to leaders to define the goals of organizations such as "who 
are we?" so by displaying good and effective behavior, subordinates will be increasingly convinced that leaders can bring the organization moving towards shared goals (Dutton et al., 2010). Because subordinates consider their leaders to be leaders who display positive values and behavior, subordinates will also form trust in their leaders in the form of providing support (Steffens et al, 2014). Some studies even say that leaders who display resentment when subordinates performed lack of work integrity will still be trusted and viewed positively since it indicates leaders display effective behavior and care about the organization growth (Shao, Wang, \& Tse, 2018; Wang, Restubog, Shao, Lu, \& van Kleev, 2015).

As all studies, this study has limitations. First,the data was taken from subordinates only, which may affect the common method bias that may occur in data retrieval through self-report (Podsakoff, MacKenzie, \& Podsakoff, 2012) primarily on organizational identification variables. Likewise, if seen from the claiming-granting mechanism belonging to DeRue and Ashford (2010), it would be proper if the leader also provides self-assessment to receive comprehensive self-evaluation and subordinates' evaluation.

Future research may need to limit common method bias, and explore other methodological avenues to investigate claiming-granting mechanism. As well, future research may want to focus on not-for-profit organizations that encirclement shared leadership. In shared leadership, leadership is seen not based on authority that belongs to one person, but rather on collaboration that maximizes cooperation between people within the organization (Kezar \& Holocombe, 2017). Further, it would be interesting to explore the reason subordinates of not-forprofit organizations that embedded shared leadership in Indonesia remain loyal and want to provide an endorsement to their leaders. Unlike profit-oriented companies, subordinates in not-for-profit organization may not be bound by some consequences if they do not deliver endorsement (there is no possible suspension, or incentives). Subsequently, it is necessary to do further research related to whether leaders in not-forprofit organization received their endorsement purely due to their prototypicality or other factors.

\section{CONCLUSION}

This study contributes to the theoretical approach in the topic of leader endorsement in Indonesia. First, the similarity of the characteristics between leader and organization becomes important for subordinates to judge whether the leader deserves endorsement. Second, in addition to being seen as prototypical-similar in characteristics-leaders can also get endorsements if they behave effectively. Thus, based on the findings of this study, there is a possibility that even lowprototypical leaders can get endorsement if they behave effectively. Third, the findings indicate that it is not only the common characteristics of leaders (prototypicality) that can form a leader endorsement but also effectiveness. This process unlocks opportunities for individuals whose characteristics are not typical to remain acceptable as leaders. The results of this study indicate that each individual can try to be accepted as a leader at least by two ways, trying to become prototypical with the organization or displaying effective behavior. Future research may want to explore this tendency to other type of organizations, such as non-for-profit organizations or organizations.

\section{REFERENCES}

Bal, P. M., de Cooman, R., \& Mol, S. T. (2013). Dynamics of psychological contracts with work engagement and turnover intention: The influence of organizational tenure. European Journal of Work and Organizational Psychology, 22(1),

107-122. 
doi:10.1080/1359432X.2011.626198

Barreto, N. B., \& Hogg, M. A. (2017). Evaluation of and support for group prototypical leaders: a meta-analysis of twenty years of empirical research. Social Influence, 12(1), 41-55. doi:10.1080/15534510.2017.1316771

Braun, S., Peus, C., \& Frey, D. (2018). Connectionism in action: Exploring the links between leader prototypes, leader gender, and perceptions of authentic leadership. Organizational Behavior and Human Decision Processes, 149, 129144. doi:10.1016/j.obhdp.2018.10.003

Brown, A. D. (2017). Identity Work and Organizational Identification. International Journal of Management Reviews, 19(3), 296-317. doi:10.1111/ijmr.12152

Chattopadhyay, P., George, E., \& Ng, C. K. (2011). An uncertainty reduction model of relational demography. In Research in Personnel and Human Resources Management (Vol. 30). https://doi.org/10.1108/S07427301(2011)0000030007Cohen, J., Cohen, P., West, S. G., \& Aiken, L. S. (2003). Applied multiple regression/correlation analysis for the behavioral sciences ( $3^{\text {rd }}$ ed). New Jersey:Lawrence Erlbaum Associates.

De Cremer, D., van Dijke, M., \& Mayer, D. M. (2010). Cooperating When "You" and "I" Are Treated Fairly: The Moderating Role of Leader Prototypicality. Journal of Applied Psychology, 95(6), 1121-1133. doi:10.1037/a0020419

Derue, D., \& Ashford, S. (2010). Who will lead and who will follow? A social process of leadership identity construction in organizations. Academy of Management Review, 35(4), 627-647. doi:10.5465/AMR.2010.53503267
Duarsa, H. C., \& Riantoputra, C. D. (2017). Leader-member exchange as a mediator in the relationship between benevolence value and leader effectiveness: An insight into the hotel industry of Bali. Asian Journal of Business and Accounting, 10(2), 281-301.

Dutton, J. E., Roberts, L. M., \& Bednar, J. (2010a). Pathways for positive identity construction at work: Four types of positive identity and the building of social resources. The Academy of Management Review, 35(2), 265-293. doi:10.5465/AMR.2010.48463334

Dutton, J. E., Roberts, L. M., \& Bednar, J. (2010b). Pathways for positive identity construction at work: four types of positive identity and the building of social resources. Academy of Management Review, 35(2), 265293.doi:10.5465/AMR.2010.48463334

Epitropaki, O., Kark, R., Mainemelis, C., \& Lord, R. G. (2017). Leadership and followership identity processes: A multilevel review. Leadership Quarterly, 28(1), 104-129. doi:10.1016/j.leaqua.2016.10.003

Ewen, C., Wihler, A., Blickle, G., Oerder, K., Ellen, B. P., Douglas, C., \& Ferris, G. R. (2013). Further specification of the leader political skill-leadership effectiveness relationships: Transformational and transactional leader behavior as mediators. Leadership Quarterly, 24(4), 516533.doi:10.1016/j.leaqua.2013.03.006

Gerpott, F. H., Van Quaquebeke, N., Schlamp, S., \& Voelpel, S. C. (2019). An Identity Perspective on Ethical Leadership to Explain Organizational Citizenship Behavior: The Interplay of Follower Moral Identity and Leader Group Prototypicality. Journal of Business Ethics, 156(4), 1063-1078. doi:10.1007/s 10551-017-3625-0 
Gleibs, I. H., \& Haslam, S. A. (2016). Do we want a fighter? The influence of group status and the stability of intergroup relations on leader prototypicality and endorsement. Leadership Quarterly, 27(4), 557-573. doi: 10.1016/j.leaqua.2015.12.001

Goldman, L., \& Hogg, M. A. (2016). Going to extremes for one's group: the role of prototypicality and group acceptance. Journal of Applied Social Psychology, 46(9), 544-553. doi:10.1111/jasp.12382

Graf, M. M., Schuh, S. C., van Dick, R., \& van Quaquebeke, N. (2012). The Relationship Between Leaders' GroupOriented Values and Follower Identification with and Endorsement of Leaders: The Moderating Role of Leaders' Group Membership. Journal of Business Ethics, 106(3), 301311.doi:10.1007/s10551-011-0997-4

Grille, A., Schulte, E. M., \& Kauffeld, S. (2015). Promoting Shared Leadership: A Multilevel Analysis Investigating the Role of Prototypical Team Leader Behavior, Psychological Empowerment, and Fair Rewards. Journal of Leadership and Organizational Studies, 22(3), 324339. doi:10.1177/1548051815570039

Hannah, S. T., Sumanth, J. J., Lester, P., \& Cavarretta, F. (2014). Debunking the false dichotomy of leadership idealism and pragmatism: Critical evaluation and support of newer genre leadership theories. Journal of Organizational Behavior, 35, 598-621. doi:10.1002/job

Haslam, S. A., (2014). Making good theory practical: Five lessons for an Applied Social Identity Approach to challenges of organizational, health, and clinical psychology. British Journal of Social Psychology, 53(1), 1-20. doi:10.1111/bjso.12061

Haslam, S. A., Reicher, S., \& Platow, M.
(2011). The new psychology of leadership: Identity, influence, and power. England: Psychology Press

He, H., \& Brown, A. D. (2013). Organizational Identity and Organizational Identification: A Review of the Literature and Suggestions for Future Research. Group and Organization Management, 38(1), 3-35. doi:10.1177/1059601112473815

Hogg, M. A. (2016). Group members differ in relative prototypicality: Effects on the individual and the group. Behavioral and Brain Sciences, 39, 153. https://doi.org/DOI: 10.1017/S0140525X15001417

Hogg, M. A., Rast, D. E., \& van Knippenberg, D. (2012). The social identity theory of leadership: Theoretical origins, Research findings, And conceptual developments. European Review of Social Psychology, 23(1), 258-304. doi:10.1080/10463283.2012.741134

Hohman, Z. P., Gaffney, A. M., \& Hogg, M. A. (2017). Who am I if I am not like my group? Self-uncertainty and feeling peripheral in a group. Journal of Experimental Social Psychology, 72, 125-132.

doi:10.1016/j.jesp.2017.05.002

Johnson, R. E., Venus, M., Lanaj, K., Mao, C., \& Chang, C. H. (2012). Leader identity as an antecedent of the frequency and consistency of transformational, consideration, and abusive leadership behaviors. Journal of Applied Psychology, 97(6), 1262-1272. doi:10.1037/a0029043

Karanika-Murray, M., Duncan, N., Pontes, H. M., \& Griffiths, M. D. (2015). Organizational identification, work engagement, and job satisfaction. Journal of Managerial Psychology, 30(8), 1019-1033. doi:10.1108/JMP-11- 
2013-0359

Kezar, A.J., \& Holcombe, E.M. (2017). Shared leadership in higher education: Important lessons from research and practice. Washington DC: American Council on Education.

Lau, V. W., Bligh, M. C., \& Kohles, J. C. (2019). Leadership as a Reflection of Who We Are: Social Identity, Media Portrayal, and Evaluations of Hillary Clinton in the 2016 U.S. Presidential Election. Sex Roles, 82, 422-437. doi:10.1007/s11199-019-01070-8

Lee, E. S., Park, T. Y., \& Koo, B. (2015). Identifying organizational identification as a basis for attitudes and behaviors: A meta-analytic review. Psychological Bulletin, 141(5), 1049-1080. doi:10.1037/bul0000012

Luksyte, A., \& Avery, D. R. (2015). Exploring burnout and work-family facilitation as factors influencing why and when relational demography diminishes employee citizenship. Journal of Occupational and Organizational Psychology, 88(4), 750772. doi:10.1111/joop.12096

Marchiondo, L. A., Myers, C. G., \& Kopelman, S. (2015). The relational nature of leadership identity construction: How and when it in fluences perceived leadership and decision-making. The Leadership Quarterly, 26(5), 892-908. doi:10.1016/j.leaqua.2015.06.006

Martin, S. R., Cote, S., \& Woodruff, T. (2016). Echoes of our upbringing: How growing up wealthy or poor relates to narcissism, leader behavior, and leader effectiveness. Academy of Management Journal, 59(6), 2157-2177. doi:10.5465/amj.2015.0680

Meleady, R., \& Crisp, R. J. (2017). Take it to the top: Imagined interactions with leaders elevates organizational identification. Leadership Quarterly, $28(5)$, 621-638. doi:10.1016/j.leaqua.2017.01.008

Ng, T. W. H., \& Feldman, D. C. (2010). Organizational tenure and job performance. Journal of Management, $36(5)$, 1220-1250. doi:10.1177/0149206309359809

Nugraha, Y., Samian, S., \& Riantoputra, C. (in press). Anteseden leader endorsement: Perspektif teori identitas sosial. Jurnal Psikologi Sosial. Retrieved from http://jps.ui.ac.id/index.php/jps/article/v iew/142

Oktug, Z. (2013). The moderating effects of age and tenure on the relationship between organizational identification and job satisfaction. Management, 3(4), 218-222.

doi:10.5923/j.mm.20130304.04

Peters, K., \& Haslam, S. A. (2018). I follow, therefore I lead: A longitudinal study of leader and follower identity and leadership in the marines. British Journal of Psychology, 109(4), 708-723. doi:10.1111/bjop.12312

Podsakoff, P.M., MacKenzie, S.B., \& Podsakoff, N.P. (2012). Sources of method bias in social science research and recommendations on how to control it. Annual Review of Psychology, 63, 539-69. doi: 0.1146/annurev-psych120710-100452

Rast, D. E., Gaffney, A. M., Hogg, M. A., \& Crisp, R. J. (2012). Leadership under uncertainty: When leaders who are nonprototypical group members can gain support. Journal of Experimental Social Psychology, 48(3), 646-653. doi:10.1016/j.jesp.2011.12.013

Rast, D. E., Hackett, J. D., Alabastro, A., \& Hogg, M. A. (2015). Revoking a leader's 
"license to fail": Downgrading evaluations of prototypical in-group leaders following an intergroup failure. Journal of Applied Social Psychology, 45(6), 311-318. doi:10.1111/jasp.12297

Rast, D. E., Hogg, M. A., \& Tomory, J. J. (2015). Prototypical Leaders Do Not Always Get Our Support: Impact of SelfUncertainty and Need for Cognition. Self and Identity, 14(2), 135-146. doi:10.1080/15298868.2014.964755

Reicher, S. D., Haslam, S. A., \& Platow, M. J. (2018). Shared social identity in leadership. Current Opinion in Psychology, 23, 129-133. doi:10.1016/j.copsyc.2018.08.006

Riyadi, N., Asakarunia, D. Wijaya, F., \& Riantoputra, C. D. (2019). The construction of positive leader identity: Acquiring a leadership position and being accepted by others, in Sendjaja, S. (ed). Leading for high performance in Asia: Contemporary research and evidence-based practices, chp. 4. Singapore: Springer.

Seppälä, T., Lipponen, J., Bardi, A., \& Pirttilä-Backman, A. M. (2012). Change-oriented organizational citizenship behaviour: An interactive product of openness to change values, work unit identification, and sense of power. Journal of Occupational and Organizational Psychology, 85(1), 136155. doi:10.1111/j.20448325.2010.02010.x

Shao, B., Wang, L., \& Tse, H. H. M. (2018). Motivational or dispositional? The type of inference shapes the effectiveness of leader anger expressions. Leadership Quarterly, 29(6), 709-723. doi:10.1016/j.leaqua.2018.04.002
Spisak, B. R., Grabo, A. E., Arvey, R. D., \& van Vugt, M. (2014). The age of exploration and exploitation: Youngerlooking leaders endorsed for change and older-looking leaders endorsed for stability. Leadership Quarterly, 25(5), 805-816.

doi:10.1016/j.leaqua.2014.06.001

Steffens, N. K., Haslam, S. A., \& Reicher, S D. (2014). Up close and personal: Evidence that shared social identity is a basis for the "special" relationship that binds followers to leaders. Leadership Quarterly, 25(2), 296313.doi:10.1016/j.leaqua.2013.08.008

Steffens, N. K., Haslam, S. A., Reicher, S. D., Platow, M. J., Fransen, K., Yang, J., ... Boen, F. (2014). Leadership as social identity management: Introducing the Identity Leadership Inventory (ILI) to assess and validate a four-dimensional model. Leadership Quarterly, 25(5), 1001-1024.

doi:10.1016/j.leaqua.2014.05.002

Uhl-Bien, M., Riggio, R. E., Lowe, K. B., \& Carsten, M. K. (2014). Followership theory: A review and research agenda. Leadership Quarterly, 25(1), 83-104. doi:10.1016/j.leaqua.2013.11.007

van Knippenberg, D. (2011). Embodying who we are: Leader group prototypicality and leadership effectiveness. Leadership Quarterly, 22(6), 1078-1091. doi:10.1016/j.leaqua.2011.09.004

Wang, L., Restubog, S., Shao, B., Lu, V., \& van Kleev, G. A. (2015). Does Anger Expression Help or Harm Leader Effectiveness? The Role of Competence-Based versus Integritybased Violations and Abusive Supervision. Academy of Management Journal, 61(3). doi: 10.5465/amj.2015.0460 